\title{
Ethno mathematics-based teaching materials for elementary school students
}

\author{
Edy Purwanto ${ }^{1 *}$ \\ Rochmiyati $^{2}$ \\ Nurhanurawati ${ }^{3}$ \\ 1,2,3Faculty of Teacher Training and Education, University of Lampung, Bandar Lampung, Indonesia
}

\begin{abstract}
This study aims to develop teaching materials based on ethno mathematics. A Research and Development (R\&D) method as used in this research. Meanwhile, the research design of teaching materials developed using ADDIE included five stages, namely analyze, design, development, implementation, and evaluation. The feasibility of this ethno mathematical-based teaching material refers to the results of the assessments of three experts, namely education expert, ethno mathematics expert, and mathematicians, as well as students' responses. The students' responses used as a trial were made by fifth-grade students of SDN Negara Bumi, Central Sungkai Subdistrict. The results of this study indicate that the teaching materials developed based on ethno mathematics have met the standards of feasibility aspects which include validity, practicality, and effectiveness of teaching materials.
\end{abstract}

\section{KEYWORDS}

Teaching material; ethno mathematics; ADDIE;

Mathematics

Received: 2 August 2021

Accepted: 14 August 2021

Published: 20 August 2021

\section{Introduction}

Teaching materials are systematically organized materials or subject matter that are utilized by teachers and students in the learning process (Amin, 2016). Furthermore, teaching materials are materials that will be taught to students who have been selected, or teaching materials are materials (messages) that students must learn and understand (Syutaridho, 2019). Therefore, it can be concluded that Teaching materials are systematically organized materials or subject matter that teachers and students employ in the learning process. Compatibility (validity), which is related to the level of acceptability and testability of the content with competency, importance (significance), usability (utility), and the ability to learn, are the principles of producing educational material (Mulyasa, 2016). Concerning the possibility of the material to be studied, both with regard to the availability and feasibility of the material to be studied and the ease of obtaining it, interest is related to the attractiveness of the material level. Thus, it can increase students' enthusiasm for learning to conduct various further studies.

In learning mathematics taught in elementary schools, most students found problems, namely, students had difficulty understanding mathematical concepts. In fact, if realized, in everyday life, people are never separated from mathematics. Stacey (2010) has demonstrated that Indonesian students are unable to relate mathematical concepts to real-life situations. Students have trouble answering real-life arithmetic problems because they have only been taught practical formulas so far. Johnson (2002) explained that "most of the students have difficulty applying mathematics in everyday life because the mathematics learning developed by the teacher is limited to memorizing formulas and understanding a few concepts." This is the initial cause of the difficulty of students in learning mathematics, namely, mathematics is left to be less meaningful (Dahlan \& Permatasari, 2018). According to (Misdalina, Zulkardi, \& Purwoko, 2009), one of the causes of the low mathematics learning achievement of students is the abstract nature of mathematics which makes most students consider mathematics difficult. Thus, mathematics is for from students' life. Explains that the one of the reasons students are un able to apply mathematics principles to real-life problems is because their teachers do not link cultural and daily activities to the learning process.

The introduction of questions that are suited to the situation should be the first step in learning mathematics (contextual problems). Students are guided to grasp mathematical topics by posing contextual puzzles

\section{CONTACT Edy Purwanto \\ (M) edypurwanto210480@gmail.com}

○ 2021 The Author(s). Published with license by Lighthouse Publishing

This is an Open Access article distributed under the terms of the Creative Commons Attribution-ShareAlike 4.0 International (CC BY-SA 4.0) License (https://creativecommons.org/licenses/by-sa/4.0/), which allows others to share the work with an acknowledgement of the work's authorship and initial publication in this journal. 
(Supinah, 2008). Mathematical concepts can be found in cultural heritage, such as traditional houses and places of worship, traditional pottery and equipment, local units, batik and border motifs, and traditional games. In order to incorporate cultural aspects into mathematics curriculum, teachers must be able to investigate mathematical phenomena in cultural elements as learning content. Ethno mathematics is the name given to these mathematical phenomena in cultural praxis (D'Ambrosio \& Rosa, 2016). Ethno mathematics can serve as a link between culture and mathematics (Tandililing, 2013). According to Amit and Fouze (2018), Ethno mathematics is a teaching approach that incorporates mathematics with the art of a country's own culture, as well as the needs and lives of its population.

One of the innovative mathematics learning in elementary school $(S D)$ can be done through providing culture-based teaching materials or what is called ethno mathematics. Teaching materials are systematically organized materials or subject matter that are utilized by teachers and students in the learning process (Amin, 2016). Ethno mathematics represents real cultural objects in mathematical concepts (Sudirman et al., 2020). Ethno mathematics-based teaching materials are defined as special teaching materials prepared by teachers in carrying out the activities of the mathematics learning process in elementary school classes related to culture, either in the form of habits that are often encountered by students. One form of ethno mathematical-based teaching materials that can be adapted is the result of cultural developments in the area itself. D'Ambrosio (1990) emphasizes that the application of mathematical abilities, concepts, methods, and practices by a group of people in the past that has been preserved till now is known as ethno mathematics. According to (Puspadewi \& Wulandari, 2018), ethno mathematics is mathematics that appears as a result of the influence of activities in the environment that are influenced by culture. Rubio (2016) says that ethno mathematics learning is a learning application that adapts to mathematical concepts in daily activities. Rosa and Orey (2016) explained that ideas, techniques, processes, methods, and practices rooted in many cultural settings are included in ethno mathematics. Learning about culture, learning with culture, and learning through culture are the three types of culture-based learning. When ethno mathematics is applied in the classroom, students learn to connect culture and mathematics. The goals of adding ethno mathematics and culturally oriented pedagogical approaches into the mathematics curriculum are to make mathematics more relevant and meaningful in the classroom, as well as to improve students' educational experiences overall (Matang \& Owens, 2014). Given that each region is made up of diverse tribal groups and civilizations, each with its own unique approach to problem solving, including ethno mathematics into the school curriculum will provide a new layer to mathematics instruction (Sirate, 2012).

A previous study conducted by Fitriyah et al. (2018) entitled "Learning Materials for Geometric Transformation Based on Discovery Learning using an Ethno mathematical Approach," found that the teaching materials applied categorized into very practical criteria as indicated by the practicality score of $84.5 \%$, indicating that the teaching materials developed are said to be effective for use in learning. Teachers are required to be able to determine appropriate learning methods and models according to the diverse abilities of students to optimally deliver the learning materials. Therefore, a professional teacher must be able to design interesting and effective teaching materials used in learning mathematics to make students easily understand the material. One of them is by using an ethno mathematical approach. Several studies on the construction of ethno mathematical-based teaching materials that can be used in learning mathematics, for example, are research on the development of ethno mathematical-based teaching materials in junior high school mathematic learning conducted by Jarnawi A. D \& Revina P (2017). The results of this study are ethno mathematics-based teaching materials in the form of student worksheets on set topics. Besides, there is also a study conducted by Fadila D. R \& Marsigit (2017), namely the development of ethno mathematical-based teaching materials to improve the achievement and learning motivation of junior high school students. The results of the study were teaching materials in the form of Student Worksheets on triangle and quadrilateral material.

Based on the description above, it is necessary to study ethno mathematics-based teaching materials in learning mathematics in elementary schools. It is expected that the use of ethno mathematical-based teaching materials can make it easier for students to understand the material.

\section{Research method}

This study is a qualitative descriptive study. The population in this study were fifth-grade elementary school students in Central Sungkai Subdistrict. The samples used were fifth-grade students at SDN Negara Bumi, Central Sungkai Subdistrict. This study was written using the literature study method which is a review of literature from journals. Technical analysis of data was conducted by summarizing, presenting, and providing conclusions. This study employed the ADDIE design (Analysis, Design, Develop, Implementation, and Evaluate).

\section{Result and discussion}

Based on research conducted on literature studies, a product was produced in the form of ethno mathematics-based mathematics teaching materials for elementary schools. Ethno mathematics-based mathematics teaching materials were produced using the ADDIE design (Analysis, Design, Develop, implementation, and Evaluate). The activities and expected results from each of these stages are as follows: 
The analysis stage was conducted to obtain an overview of the social and cultural values of the community such as interviews to explore and observe community activities, interviews with students to obtain information on barriers to learning mathematics, interviews with teachers to obtain information on barriers to learning design development, and the possibility of applying ethno mathematics, as well as analyzing mathematics curriculum in elementary school. It was expected that ethno mathematics would emerge in the community, as well as issues in elementary mathematics curriculum content that could be utilized as models for building ethno mathematical-based teaching materials or socio-cultural values that could be incorporated into teaching materials.

The design stage is an ethno mathematics-based model study of teaching materials which included: Preparation of the format of teaching materials; The selection of the approach to presenting the content of teaching materials was based on the approach and learning model proposed by the 2013 curriculum, namely using scientific approach; At the end of this stage, a blueprint for writing ethno mathematical-based teaching materials was obtained.

The Develop stage is the implementation of the blueprint produced from the design stage with the following steps: Preparation of syllabus and lesson plans on one of the selected topics. The format of the syllabus and lesson plans was following the 2013 curriculum; Development of teaching materials in the form of learning modules based on ethno mathematics obtained in the results of the first stage; Validation of experts involved 3 experts, namely mathematics education, mathematics, and socio-anthropology, especially those who understand the culture of society.

The implementation stage is the first trial phase of the research. The information that is of concern at this stage is the barriers of students in learning mathematics with ethno mathematical-based teaching materials that have been developed; Barriers to teachers in using learning resources from ethno mathematical-based teaching materials; Student learning outcomes in mathematics on related topics. Learning outcomes included cognitive, affective, and psychomotor.

The evaluation stage contains two activities, namely implementation reflection, and revision of teaching materials based on the results of implementation reflection. The implementation of the reflection stage was carried out to review the obstacles that arise during implementation both from students and from teachers, as well as analysis of the results of the assessment of students. Then, the data obtained were used to improve the teaching materials that had been designed, in order to obtain revised ethno mathematical-based teaching materials.

The initial step taken in making ethno mathematical-based mathematics teaching materials was to elaborate on the social and cultural values of the community that may be integrated into mathematics teaching materials. This activity was carried out by interviewing several respondents consisting of community leaders, teachers, and students. The results of interviews with teachers and community leaders obtained information that the social and cultural values that exist in society are quite a lot to be used as tools in learning mathematics. For example, the shape of the roof of the house, handicrafts, traditional food, traditional children's games, traditional arts, and others. Several other traditional objects can be used as school mathematics learning equipment/materials, such as mother tongue, house building forms, handicrafts, and community activities in farming.

The results of the analysis of the elementary mathematics curriculum and interviews with teachers, students, and principals obtained an agreement that the teaching materials developed were the subject matter. The form of presentation of systematic teaching materials was adjusted to the characteristics of the material discussing direct mathematical objects, such as facts and concepts. This is as recommended by Bell (1978) that for direct object material, mathematics should use learning models, while for material involving mathematical principles and procedures. The chosen design was to develop learning tools that include teaching materials in the form of a Learning Module.

Ethno mathematics-based teaching materials provide a different look. Thus, students can be more motivated and enthusiastic about learning mathematics. This supports a previous study conducted by Fitriyah (2018) entitled Learning Materials for Geometry Transformation Based on Discovery Learning through the Ethno mathematical Approach, that the development of ethno mathematical-based teaching materials can easily provide students with an understanding of the material presented, as well as get to know the culture that has to do with mathematical concepts compared to memorizing formulas.

In the 2013 Curriculum, the cultural element is one of the things that is emphasized in the achievement of the 2013 Curriculum. As the perspective of Wahyuni et al. (2013) holds that learning mathematics requires an approach to provide effective learning and students are able to master the content or material being taught and apply it in solving problems. Fitriatien (2016) states that socio-cultural values cannot be separated from mathematics which is bridged by ethno mathematics. Thus, ethno mathematics-based learning is an improvement effort in improving the quality of mathematics learning. 


\section{Conclusion}

The ethno mathematics-based teaching materials developed have met the feasibility aspects of teaching materials which include validity, practicality, and effectiveness based on the results of validation activities by experts. The validation of teaching materials was carried out by three experts, namely the education expert test, the ethno mathematics expert test, and the mathematician test. Furthermore, small group and large group trials were also conducted for fifth-grade students of SDN Negara Bumi in Central Sungkai Subdistrict, which served as the main target of developing this ethno mathematics-based teaching material. Based on the testing process, it shows that this ethno mathematics-based teaching material is valid, practical, and feasible to use. Meanwhile, the revision provided by the validator might provide improvements for teaching materials to be even better. These ethno mathematical-based teaching materials should be disseminated and utilized in learning, especially during the Covid19 pandemic where learning is carried out online.

\section{References}

Afrizal, I. M., \& Jarnawi A. D. (2017). The impact of mathematical models of teaching materials on square and rectangle concepts to improve students' mathematical connection ability and mathematical disposition in middle school. AIP Conference Proceedings, 1848 (1).

Amin, M. (2016). Panduan pengembangan bahan ajar IPA. Jakarta: Direktorat Jendral Dikdas.

Bell, F.H. (1978). Teaching and learning mathematics in scondary school. New York: Wm C Brown Company Publiser.

D’Ambrosio, U. (1990). Etnomatemática [ethnomathematics]. São Paulo, Brazil: Editora Ática.

Dahlan, A. J., \& Permatasari, R. (2018). Pengembangan bahan ajar berbasis etnomatematika dalam pembelajaran matematika sekolah menengah pertama. Jurnal Nasional Pendidikan Matematika. 2(1), 133-150.

Fitriatien, S. R. (2016). Pembelajaran berbasis etnomatematika. Surabaya: Universitas PGRI Adi Buana Surabaya.

Fitriyah, D. N., Santoso, H. \& Suryadinata, N., (2018). Bahan Ajar Transformasi Geometri Berbasis Discovery Learning melalui Pendekatan Etnomatematika. J. Elem, 4(2), 145.

Fouze, Abu Qouder., \& Amit, Miriam. (2018). Development of mathematical thinking through integration of ethnomathematic folklore game in math instruction. EURASIA J Math Sci Tech Ed. 14(2), 617-630.

Johnson, S., Johnson, L., (2002). The 4 Cs: a model for teaching dosage calculation. Nurse Educator. 27(2), 79-83.

Matang, Rex A. S., \& Owens, Kay. (2014). The role of indigenous traditional counting systems in children's development of numerical cognition: results from a study in Papua New Guinea. Mathematics Education Research Journal. $26,531-553$.

Mulyasa. (2016). Revolusi dan inovasi pembelajaran sesuai standar proses. Bandung: Rosda.

Misdalina, Zulkardi, \& Purwoko. (2009). Pengembangan materi integral untuk sekolah menengah atas (SMA) menggunakan pendekatan pendidikan matematika realistik indonesia (PMRI) di palembang. Jurnal Pendidikan Matematika, 3(1), 61-74.

Puspadewi, Kadek Rahayu., \& Wulandari, I Gusti Ayu Putu Arya. (2018). Analisis etnomatematika jejahitan bali dalam pembelajaran bangun datar. Jurnal Bakti Saraswati: Media Publikasi Penelitian dan Penerapan IPTEKS. 7(2), 145 - 156.

Rahmawati, Fadila Dyah., \& Marsigit, Marsigit. (2017). Pengembangan bahan ajar berbasis etnomatematika untuk meningkatkan prestasi dan motivasi belajar siswa sekolah menengah pertama. Thesis: UNY.

Rosa, M., D`Ambrosio, U., Orey, D.C. Shirley, L., Alangui, M.V., Palhares, P., \& Gavarrete, M.E., (2016). Curret and future perpectives of ethnomathematics as a program. ICME-13 Topical Surveys, Springer Nature Switzerland.

Rubio, J. S. (2016). The ethnomathematics of the Kabihug tribe in Jose Panganiban, Camarines Norte, Philippines. Malaysian Journal of Mathematical Sciences. 10, 211-231.

Stacey, Kaye. (2010). The PISA view of mathematical literacy in Indonesia. Journal on mathematics education (IndoMS-JME), 2.

Sirate, S. Fatimah. (2012). Implementasi etnomatematika dalam pembelajaran matematika pada jenjang pendidikan sekolah dasar. Lentera Pendidikan, 15(42), 41-54.

Sudirman, S., Yaniawati, R. P., Melawaty, M., \& Indrawan, R. (2020). Integrating ethnomathematics into augmented reality technology: Exploration, design, and implementation in geometry learning. Journal of Physics: Conference Series, 1521.

Supinah. (2008). Pembelajaran matematika SD dengan pendekatan kontekstual dalam Melaksanakan KTSP. Jakarta: Pusat Pengembangan dan Pemberdayaan Pendidik dan Tenaga Kependidikan Matematika.

Syutaridho. (2019). Pengembangan bahan ajar bangun datar dengan pendekatan contextual teaching and learning. Jurnal Pendidikan Matematika RAFA, 1 - 7.

Tandililing, E. (2013). Pengembangan pembelajaran matematika sekolah dengan pendekatan etnomatematika berbasis budaya lokal sebagai upaya untuk meningkatkan kualitas pembelajaran matematika di sekolah. Jurnal Prosiding di Seminar Nasional Matematika dan Pendidikan Matematika, 180 - 187. 